\title{
Relative Poverty Measurement by Equivalent Income
}

\author{
Case of Volga Federal District Regions in the Russian Federation
}

\author{
Ruslan Sadyrtdinov, Dmitry Rodnyansky \\ Institute of Management, Economics and Finance \\ Kazan Federal University \\ Kazan, Russian Federation \\ s_ryslan@mail.ru,drodnyansky@gmail.com
}

\author{
Ivan Makarov, Olga Shirokova \\ Department of Economics, Management and Marketing \\ Finance University under the Government of the Russian \\ Federation (Lipetsk Branch) \\ Lipetsk, Russian Federation \\ excellenzz@mail.ru, shirokova-ov@mail.ru
}

\begin{abstract}
In the article results of the relative poverty measurement by equivalent income for households of Volga Federal District in the Russian Federation are presented. Using equivalence scales, the authors estimate equivalent incomes and distribute households in the form of the stratification scale. Based on the research, the following conclusions are made. The majority of households in almost all regions belong to the lowermiddle class (second group), but not to the middle class (third group). Percentage is different for these regions, but on average, it is $38.9 \%$. Only two regions: the Republic of Mordovia and the Republic of Udmurtia, have more households in the third group which refers to the middle class. In almost all regions of Volga Federal District, the percentage of households below the relative poverty line is less than $10 \%$. In all regions, the proportion of households in the upper-middle and upper class together does not exceed $30 \%$ of the whole sample. The third hypothesis is confirmed.
\end{abstract}

Keywords-economics; equivalent income; relative poverty; region; Volga Federal District; Russian Federation

\section{INTRODUCTION}

The Volga Federal District includes 14 regions of the Russian Federation, including Republic of Bashkortostan, Republic of Mariy-El, Republic of Mordovia, Republic og Tatarstan, Republic of Udmurtia, Republic of Chuvashia, Kirovskaya oblast, Nizhegorodskaya oblast, Orenburgskaya oblast, Penzenskaya oblast, Samarskaya oblast, Saratovskaya oblast, Ulyanovskaya oblast and Permskiy kray.

The Volga Federal District (VFD) is located in the center of the European part of the Russian Federation. Its area is $7.27 \%$ of the territory of the Russian Federation. A multinational population live here $-22.1 \%$ of the total number of Russian citizens. It is the second most populated federal district after the Central Federal District. The population consists of people living in cities and towns. For example, in Samarskaya oblast, this figure is more than $80 \%$, in Nizhegorodskaya oblast - 78\%, in Permskiy kray - $76 \%$, which is slightly higher than the national average (about $73 \%$ ).

The number of VFD residents decreases. In the period between two population censuses (2002-2010), the population was reduced by 1.2 million people, or by $4 \%$ (while the population of the Russian Federation decreased by $1.6 \%$ ). The population declined in all regions of the district, with the exception of the Republic of Tatarstan, where its growth was noted at $0.2 \%$ due to the excess of migration growth over natural decline. The largest decrease in the population occurred in Kirovskaya oblast (by 12.2\%), the Republic of Mordovia (7.9\%) and Orenburgskaya oblast (7.5\%), the lowest - in Samarskaya oblast $(0.8 \%)$. In 2014, in comparison with 2013, the population increased in 3 regions of the district - in the Republic of Bashkortostan, the Republic of Tatarstan and Permskiy krai.

Unlike the Center Federal District, the Volga Federal District is polycentric. Several regions are roughly equal in terms of the level of development, economic weight and population. They compete for leadership, although officially the capital of the district is Nizhny Novgorod. The absence of a dominant economic and demographic center is complemented by the internal incoherence of space and the road network; all major transport routes are oriented toward Moscow.

Regions of the Volga Federal District can be divided into three groups by the level of their economic development. The more developed regions include the Republic of Tatarstan and the Republic of Bashkortostan, Permskiy krai and Samarskaya oblast with per capita gross regional product (GRP) above the Russian average or close to it. All these regions have diversified economy with developed industry. They combine the branches of the export economy, mainly oil and chemical, with a developed food industry and engineering. In these leading regions, the highest population incomes are observed in comparison with other regions of the district. Each has a large city with a population more than one million people. Samarskaya oblast has the third largest agglomeration in the country (Samara-Togliatti), which creates additional advantages for the development of the services sector. The Republic of Tatarstan has two existing agglomerations (Kazan and Naberezhnyye Chelny) and one perspective (Almetyevsk).

The second group of regions refers to the mediumdeveloped; the structure of their economy is different. In Nizhegorodskaya oblast and the Republic of Udmurtia, it is mainly industrial, with a high share of engineering, and in the 
more southern Orenburgskaya oblast and Saratovskaya oblast - industrial and agrarian. Being similar in indicators of the economic development, these regions differ significantly in social issues.

The third group includes all other regions with a quarter of the population of the Volga Federal District and is characterized by a lower level of development. The problems of these regions are mainly determined by the prevalence of machine engineering in economy. It experienced a strong decline in the 90's years of the last century and is still uncompetitive on the global level. As a consequence, the per capita GRP in Penzenskaya oblast and Ulyanovskaya oblast, it is almost twice as low as the average for the regions of the Russian Federation (with an adjustment for the cost of living). Republics of Chuvashia, Mordovia and Mari El experience the same problems with stagnation of labor-intensive machine engineering. Nevertheless, the economic situation in the Republics of Chuvashia and Mordovia is somewhat better than Mari El, because of better conditions for agriculture providing raw materials to the local food industry. In Kirovskaya oblast, the depressed state of machine engineering is supplemented by problems of undeveloped infrastructure and forestry.

\section{LITERATURE REVIEW}

The global financial crisis of 2008 sharpened the problems of inequality and poverty in many countries all over the world. One of its results might be deepening the regional disparities in household welfare and widening economic and social discrimination as a result of income inequality. Nowadays it is still a problem to get data on income inequality at the regional level, failing to respond to a rising demand from policymakers and local authorities. At the same time, there is certain number of works related to the study of poverty and income inequality in different regions.

Chung, Isaacs and Smeeding use the American Community Survey and Wisconsin administrative data to estimate trends in the poverty rates in Wisconsin for the overall population, for children, and for the elderly between 2008 and 2010. They use an alternative poverty measure similar to the federally implemented Supplemental Poverty Measure (SPM) but customized to reflect the place-specific needs and resources of Wisconsin. Unlike the official poverty measure, the Wisconsin Poverty Measure (WPM) considers tax credits and noncash benefits and adjusts for work-related and medical care expenses and relative living costs statewide and across sub-state regions. Although state poverty levels calculated via the official measure continued to increase between 2008 and 2010; WPM shows essentially no change in state poverty rates between 2008 and 2009 and a decline between 2009 and 2010 [1] .

In the research of Annoni, Bruggemann and Carlsen, an alternative to aggregation based on simple concepts of partial order theory is proposed. Illustrating the pros and cons of this approach, a multidimensional measure of poverty comprising three components - absolute poverty, relative poverty and income, is taken as case study. The analysis enables one to highlight conflicts across the components with some European Union regions detected as controversial, with, for example, low levels of relative poverty and high levels of monetary poverty. The partial order approach enables one to point to the regions with the most severe data conflicts and to the component indicators that cause these conflicts. [2]

Using the European Union Statistics on Income and Living Conditions (EU-SILC), Longford, Pittau and Zelli provide a comprehensive map of median income, inequality (Gini coefficient and Lorenz curve) and poverty (poverty rates) based on the equivalised household income in the countries in which the EU-SILC is conducted. They study the distribution of income of households (pro-rated to its members), not merely its median (or mean), because they regard its dispersion and frequency of lower extremes (relative poverty) as important characteristics. The estimation for the regions with small sample sizes is improved by the small-area methods. The uncertainty of complex nonlinear statistics is assessed by bootstrap. Household-level sampling weights are taken into account in both the estimates and the associated bootstrap standard errors. [3]

Han, Liu and Zhang examine the impact of globalization on wage inequality using Chinese Urban Household Survey data from 1988 to 2008. Exploring two trade liberalization shocks, Deng Xiaoping's Southern Tour in 1992 and China's accession to the World Trade Organization (WTO) in 2001, they analyze whether regions more exposed to globalization experienced larger changes in wage inequality than lessexposed regions. Contrary to the predictions of the HeckscherOhlin model, they found that the WTO accession was significantly associated with rising wage inequality. They showed that both trade liberalizations contributed to withinregion inequality by raising the returns to education (the returns to high school after 1992, and the returns to college after 2001) [4].

Analyzing the determinants of economic inadequacy, Zanin uses cross-sectional microdata collected through a structured questionnaire from a 2012 survey of household income and wealth conducted by the Bank of Italy. The results of the analysis show that the probability of economic inadequacy for Italian households is higher when the household is located in regions in southern Italy. It has a low equivalent income, registers a decrease in income compared with that of a normal year, has a low liquidity ratio, pays rent for the house of residence, is over-indebted, is indebted to friends and relatives, and has an unhappy and impatient household head. He also proposes constructing a composite indicator at the regional level that combines the percentage of households in relative poverty, as measured by the Italian National Institute of Statistics, and the percentage of households that is identified as existing in a condition of economic inadequacy [5].

Cerqueti and Ausloos discuss region wealth size distributions, through their member cities aggregated tax income. They use the official data of the Italian Ministry of Economics and Finance for all Italian municipalities, over the period of 2007-2011. Yearly data of the aggregated tax income are transformed into a few indicators: the Gini, Theil, and Herfindahl-Hirschman indices. On one hand, the relative interest of each index is discussed. On the other hand, numerical results confirm that Italy is divided into very 
different regional realities, a few which are specifically outlined. This shows the interest of transforming data in an adequate manner and of comparing such indices [6].

Another paper is about measuring poverty to better target EU local policies. Annoni and Weziak-Bialowolska propose a measurement of poverty at the sub national level in the EU by means of three poverty components describing absolute poverty, relative poverty and earnings and incomes. The core data source is the cross-sectional European Statistics on Income and Living Conditions (EU-SILC) micro-data, waves 2007-2009. Data reliability at the sub-national level is statistically assessed and the regional level is described whenever it is possible. To calculate the poverty components, an inequality-adverse type of aggregation is applied in order to limit compensability across indicators, populating a component. No aggregation is, however, performed across the three components. In the computations of income-related indicators, individual disposable income adjusted for housing costs, used as a proxy for the costs of living, is used. Poverty is confirmed to be a multi-faceted phenomenon with clear within-county variability. This variation depends on the type of region likely linked to the urbanization level and, consequently, to the costs of living. The proposed measure may serve to better target anti-poverty measures at the local, sub-national level in the EU [7] .

Blinder decompositions at the mean as well as at different quantiles of welfare distributions on regionally representative household survey data from Brazil, Skoufias and Katayama find that household attributes account for most of the welfare differences between urban and rural areas within regions. However, comparing the lagging Northeast region with the leading Southeast region, differences in the welfare gains of attributes are associated with a large part of the welfare disparities, in particular in metropolitan areas, supporting the presence of agglomeration effects in booming areas [8].

Ali, Barrientos, Saboor and Khan in their paper disaggregate Poverty Equivalent Growth Rate (PEGR) in urban-rural sectors of Pakistan and across its provinces to measures growth pro-poorness in both relative and absolute terms from 2001 to 2012. Results show an overall counteracting effect of increased inequality on growth elasticity of poverty at the national level but with significant regional contrast. Growth at the urban level is found pro-poor (anti-poor) for all poverty measures in relative (absolute) term. This is contrary to the rural regions that experienced antipoorness in both relative and absolute terms. The growth rate and the degree of pro-poorness exhibited inverse relationship during different sub-periods. Sub-national PEGR analysis shows the differential pattern of pro-poorness across regions and time. Authors suppose that consistent doses of long term pro-poor and distributive policies through fiscal and monetary management can be a workable option to minimize the gap between the rich and the poor [9].

Analyzing household expenditure dynamics in OECD countries Varlamova and Larionova shows a significant change in the period of economic crisis: during the global economic crisis and the recession in Europe. Change of household expenditures occurs under the influence of such macroeconomic factors as disposable income of households, government spending, inflation, the interest rate that should be considered in public policies. They show that population and the education level of population is significant demographic factors that influence consumer spending and household spending on health [10].

There is also a set of papers devoted to inequality research in modern Russia. Studying the post-soviet period most authors conclude that while going through inequality of transformation process income and the number of poor households increased substantially in Russia. There are two more interesting conclusions from these papers. Firstly, families with many children have a high level of poverty. Secondly, a high correlation between poverty and a low level of education and unemployment exists. For example, Klugman [11] in his paper finds out that in the 1990s, Russian households with three or more children and households with one or more disabled persons belong to the poorest group.

There are papers with analysis of inequality and poverty in the Russian Federation compared to developed countries and countries in transition. Among them, Milanović [12] and Bradbury, Jenkins and Mikelright [13] papers can be mentioned. Milanovic in his research describes the effects of the transformation process that the CIS, Eastern Europe and the Baltic States came through on their way to market economy, on the households welfare. Moreover, special poverty features are distinguished for all of these states in his paper. Jenkins and Mikelright chose the US, Britain, Germany, Ireland, Spain, Hungary and Russia for their research. One of the conclusions that they made is that households with children in Russia in the late 1990s have the highest level of inequality in both expenditure and income in comparison with other countries.

Korchagina and Ovcharova [14], studying the level of poverty in Russia, came to a conclusion that the Federal Service for State Statistics of the Russian Federation underestimates poverty by an average of $8-20 \%$. It uses the minimum consumer basket for poverty line assessment and disregards the economies of scale in household consumption. Relation between long-term poverty and different demographic and regional features of households, such as unemployment or delays in wage payments, is studied in Braithwaite and Ivanova [15] paper.

In all above-mentioned researches on poverty and inequality in Russia, the absolute concept of poverty is used. Another one is a relative concept of poverty, and poverty scales in these two cases usually do not coincide. Eradication of relative poverty is impossible in the modern world, because inequality is inherent in it. In order to measure relative poverty, it is needed to estimate a relative poverty line for which the percentage of median per capita income (in this paper $40 \%$ of the median income) is usually taken. Then distribution of household income from the sample is made relative to the poverty line.

In this paper, authors use the sample of households living in the regions of the Volga Federal District and estimate relative poverty line for distribution of households by equivalent income towards it. And the first hypothesis to 
check $-50 \%$ or more of households in the majority of Volga Federal District regions belongs to the middle class. The second hypothesis - in almost all regions of Volga Federal District, the percentage of households below the relative poverty line is less than $10 \%$. Third hypothesis - proportion of households in upper-middle and upper class together does not exceed $30 \%$ of the whole sample for all regions of Volga Federal District.

\section{METHODS OF RESEARCH}

Relative poverty is measured by distributing households on the scale according to their equivalent incomes. The scale consists of five intervals. The relative poverty line is set up as the boundary between the first and second intervals. To estimate poverty line $40 \%$ of median equivalent income $(M)$ of household sample is taken. In order to estimate the boundaries for other intervals, the middle of the third interval is equal to median equivalent income. Then the boundary between second and third intervals is set up as $80 \%$ of $M$, With the same step in relation to $M$, the boundaries for two subsequent intervals are set. In other words, the boundary between the first and second intervals is $0.4^{*} M$, for the second and third intervals $-0.8^{*} M$, for the third and fourth intervals $1.2 * M$, for the fourth and fifth intervals $-1.6^{*} M$

In order to take into account economies of scale, the authors estimate equivalent income for all households in the sample. It is calculated by authors on the basis of equivalence scales from Table 1, which are estimated by Beglova and Sadyrtdinov [16].

TABLE I. Estimated EQUiVALENCE SCALES FOR VOlga FEDERAL DISTRICT REGIONS OF THE RUSSIAN FEDERATION

\begin{tabular}{|c|c|c|}
\hline $\begin{array}{l}\text { Household } \\
\text { composition }\end{array}$ & $\begin{array}{l}\text { Estimated } \\
\text { scale }\end{array}$ & Region of the Russian Federation \\
\hline 1 adult & 1 & All Russian regions \\
\hline \multirow{3}{*}{$\begin{array}{l}\text { to the second } \\
\text { adult }\end{array}$} & $<0.25$ & $\begin{array}{c}\text { Penzenskaya oblast, Republic of } \\
\text { Tatarstan, Republic of Udmurtia, } \\
\text { Kirovskaya oblast, Republic of } \\
\text { Bashkortostan, Orenburgskaya } \\
\text { oblast }\end{array}$ \\
\hline & $0.25-0.4$ & $\begin{array}{l}\text { Samarskaya oblast, Permsky krai, } \\
\text { Ulyanovskaya oblast, Republic of } \\
\text { Mary El, Republic of Chuvashia, } \\
\text { Saratovskaya oblast, } \\
\text { Nizhegorodskaya oblast }\end{array}$ \\
\hline & $0.4-0.6$ & Republic of Mordovia \\
\hline \multirow{3}{*}{ to each child } & $<0.25$ & $\begin{array}{c}\text { Penzenskaya oblast, Republic of } \\
\text { Chuvashia, Republic of Tatarstan, } \\
\text { Orenburgskaya oblast }\end{array}$ \\
\hline & $0.25-0.4$ & $\begin{array}{l}\text { Republic of Udmurtia, Samarskaya } \\
\text { oblast, Republic of Mary El, } \\
\text { Republic of Mordovia, } \\
\text { Saratovskaya oblast, Ulyanovskaya } \\
\text { oblast, Kirovskaya oblast, Republic } \\
\text { of Bashkortostan, Permsky krai }\end{array}$ \\
\hline & $>0.4$ & Nizhegorodskaya oblast \\
\hline
\end{tabular}

So, authors use equivalence scales from Table 1 to adjust the household income in all regions of Volga Federal District regions. Household's equivalent income is estimated as a fraction with total household income for the month as the numerator and corresponding equivalence scale as denominator. The formula of equivalent income calculation is given below:

$$
E_{i}=\frac{H_{i}}{S}
$$

where $E_{i}$ - equivalent income of household $i$ per month,

$H_{i}$ - total income of household $i$ per month,

$S$ - equivalence scale.

Household Budget Survey in the Russian Federation for 2013 [17] is used to gain values of household total income per month, gender and age of all household members for Volga Federal District regions. This survey is held in all regions of the Russian Federation, except the Chechen Republic. Household sample is regionally representative by all indications, including gender, age, geographic location, family composition. In 2013, there are data for 51320 households in this survey. All households living in Volga Federal District regions are taken by the authors for research, because values for all needed indicators are found in the questionnaire.

\section{RESULTS AND DISCUSSION}

At first, authors estimated equivalent incomes by adjusting household total incomes using equivalence scales from Table 1. After it, median equivalent income was found for each region of Volga Federal District. To allocate intervals on the scale, the boundaries were calculated. Then authors made a distribution of all households in each selected region relative to those intervals. As it can be seen in Table 2, results of households' distribution using their equivalent incomes differ for all regions of the Volga Federal District.

TABLE II. HOUSEHOLDS DISTRIBUTION IN VOLGA FEDERAL DISTRICT REGIONS

\begin{tabular}{|c|c|c|c|c|c|}
\hline \multirow{2}{*}{ Region } & \multicolumn{5}{|c|}{ Households distribution by equivalent incomes, } \\
\cline { 2 - 6 } & $\mathbf{1}$ group & $\mathbf{2}$ group & $\mathbf{3}$ group & 4 group & 5 group \\
\hline $\begin{array}{c}\text { Republic of } \\
\text { Mordovia }\end{array}$ & 13.6 & 27.7 & 35.2 & 13 & 10.5 \\
\hline $\begin{array}{c}\text { Ulyanovskaya } \\
\text { oblast }\end{array}$ & 11.7 & 34.4 & 26.4 & 13.7 & 13.8 \\
\hline $\begin{array}{c}\text { Republic of Mari } \\
\text { El }\end{array}$ & 8.9 & 37.1 & 31 & 12.1 & 11 \\
\hline $\begin{array}{c}\text { Saratovskaya } \\
\text { oblast }\end{array}$ & 8.3 & 33.4 & 33.1 & 11.8 & 13.5 \\
\hline \begin{tabular}{c} 
Permskiy krai \\
\hline $\begin{array}{c}\text { Samarskaya } \\
\text { oblast }\end{array}$
\end{tabular} & 3.8 & 39 & 29.8 & 13.6 & 10.8 \\
\hline $\begin{array}{c}\text { Orenburgskaya } \\
\text { oblast }\end{array}$ & 3.4 & 43.6 & 28.4 & 12.2 & 12.5 \\
\hline $\begin{array}{c}\text { Nizhegorod- } \\
\text { skaya oblast }\end{array}$ & 3.1 & 37 & 35 & 14.8 & 10.2 \\
\hline $\begin{array}{c}\text { Kirovskaya } \\
\text { oblast }\end{array}$ & 2.9 & 51 & 26.5 & 11.1 & 8.4 \\
\hline $\begin{array}{c}\text { Republic of } \\
\text { Chuvashia }\end{array}$ & 2.9 & 37.2 & 35.7 & 14.4 & 9.7 \\
\hline $\begin{array}{c}\text { Republic of } \\
\text { Bashkortostan }\end{array}$ & 2.2 & 41.9 & 31.3 & 12.5 & 12.1 \\
\hline
\end{tabular}




\begin{tabular}{|c|c|c|c|c|c|}
\hline $\begin{array}{c}\text { Republic of } \\
\text { Tatarstan }\end{array}$ & 1.8 & 47.2 & 27.1 & 11.9 & 12.1 \\
\hline $\begin{array}{c}\text { Penzenskaya } \\
\text { oblast }\end{array}$ & 1.1 & 40.3 & 31.2 & 16.3 & 11.2 \\
\hline $\begin{array}{c}\text { Republic of } \\
\text { Udmurtia }\end{array}$ & 0.6 & 37.6 & 38 & 13.1 & 10.7 \\
\hline
\end{tabular}

Table 2 shows that only in two Volga Federal District regions: Republic of Mordovia and Ulyanovskaya oblast, the percentage of households below the relative poverty line is more than $10 \%$. And only the Republic of Udmurtia and Penzenskaya oblast have almost $1 \%$ and less of households below the relative poverty line. It is possible to divide other regions into two cohorts. In Samarskaya oblast, Orenburgskaya oblast, Nizhegorodskaya oblast, Kirovskaya oblast, the Republic of Chuvashia, the Republic of Bashkortostan and the Republic of Tatarstan proportion of households, who are poor in terms of relative poverty, is within $1.1-3.5 \%$. The republic of Mari El, Saratovskaya oblast, Permskiy krai can be united in the second cohort, where percentage of households that are below the poverty line is within $6.8-8.9 \%$.

The majority of households in 12 regions are in the second group and can be called the lower-middle class. Percentage is different for these regions, but on average, it is $38.9 \%$. Only two regions: the Republic of Mordovia and the Republic of Udmurtia, have more households in the third group which refers to middle class.

The proportion of households in the middle class group is different for all regions and is within 26.4-38 \%. In Ulyanovskaya oblast, Permskiy krai, Orenburgskaya oblast, Kirovskaya oblast and the Republic of Tatarsta, it does not exceed $30 \%$. There are no regions in Volga Federal District where the proportion of middle class households included in the third group exceeds $50 \%$ of the whole sample.

In group 4, the households can be classified as the uppermiddle class. In all regions of Volga Federal District, their percentage is less than $20 \%$. Minimum $(11.1 \%)$ is in Kirovskaya oblast. There are four regions (Ulyanovskaya oblast, Saratovskaya oblast, Orenburgskaya oblast, the Republic of Tatarstan), where proportion of households in the upper-middle class (group 4) is less than in the upper class (group 5). Other regions show opposite results.

Household distribution on the scale consisting of five intervals shows that in all regions, the proportion of the uppermiddle and upper class is approximately the same and together does not exceed $30 \%$ of the whole sample. The situation in other three groups differs for selected regions. It can be said that there are successful regions in poverty reduction. At the same time, these regions fail to significantly increase the proportion of middle class households. There are no regions, where the share of the middle class households exceeds the share of households included in the first two groups (poor and low-middle class).

In Russia, the absolute concept of poverty is used officially. Absolute poverty line is estimated at the level of subsistence minimum (SM). The amount of the subsistence minimum includes the cost of consumer basket (food and nonfood products), and also compulsory payments and fees.
Before 2013 subsistence minimum was estimated in accordance with Federal Law No. 134-FZ of 24.10.1997 "On the Subsistence Minimum in the Russian Federation". The amount of non-food products was measured in physical terms. For example, how many boots a person need to use for a year.

In 2013, there were changes in the subsistence minimum calculation. The minimum set of food products included in consumer products is now measured in natural terms. The cost of non-food products is estimated as half of the food cost. Consumed services constitute another quarter of the total basket cost. The new order of calculation, as explained in the resolution, allows for real changes in the cost of non-food goods and services in the consumer basket.

Table 3 shows the subsistence minimum for all regions and median monetary income for households from five groups. The amount of the subsistence minimum does not exceed median equivalent incomes in all groups except first one. So, most households, being poor in terms of relative poverty, are also below the absolute poverty line.

TABLE III. SUBSISTENCE MINIMUM AND MEDIAN INCOME FOR FIVE GROUPS OF HOUSEHOLDS IN VOLGA FEDERAL DisTRICT REGIONS, RUSSIAN RUBLES

\begin{tabular}{|c|c|c|c|c|c|c|}
\hline \multirow[b]{2}{*}{ Region } & \multirow[b]{2}{*}{ SM } & \multicolumn{5}{|c|}{ Median equivalent income } \\
\hline & & $\begin{array}{c}1 \\
\text { group }\end{array}$ & $\begin{array}{c}2 \\
\text { group }\end{array}$ & $\begin{array}{c}3 \\
\text { group }\end{array}$ & $\begin{array}{c}4 \\
\text { group }\end{array}$ & $\begin{array}{c}5 \\
\text { group }\end{array}$ \\
\hline $\begin{array}{l}\text { Republic of } \\
\text { Mordovia }\end{array}$ & 6260 & 4952 & 7666 & 10846 & 15323 & 23634 \\
\hline $\begin{array}{c}\text { Ulyanovskaya } \\
\text { oblast }\end{array}$ & 6472 & 5082 & 10057 & 16238 & 22555 & 37386 \\
\hline $\begin{array}{c}\text { Republic of } \\
\text { Mari El }\end{array}$ & 6198 & 5065 & 8909 & 13572 & 19213 & 33270 \\
\hline $\begin{array}{c}\text { Saratovskaya } \\
\text { oblast }\end{array}$ & 6126 & 4951 & 9458 & 15841 & 21950 & 34007 \\
\hline Permskiy krai & 7361 & 5540 & 11404 & 18297 & 25591 & 46036 \\
\hline $\begin{array}{c}\text { Samarskaya } \\
\text { oblast }\end{array}$ & 7482 & 6044 & 12940 & 20307 & 28947 & 46772 \\
\hline $\begin{array}{c}\text { Orenburg- } \\
\text { skaya oblast }\end{array}$ & 6131 & 4674 & 12449 & 21670 & 29866 & 54118 \\
\hline $\begin{array}{l}\text { Nizhegorod- } \\
\text { skaya oblast }\end{array}$ & 6488 & 5459 & 10677 & 16616 & 22888 & 35677 \\
\hline $\begin{array}{c}\text { Kirovskaya } \\
\text { oblast }\end{array}$ & 6905 & 5387 & 14117 & 24013 & 34731 & 90032 \\
\hline $\begin{array}{c}\text { Republic of } \\
\text { Chuvashia }\end{array}$ & 6049 & 4538 & 9830 & 15979 & 22470 & 36030 \\
\hline $\begin{array}{c}\text { Republic of } \\
\text { Bashkortostan }\end{array}$ & 6446 & 5442 & 12697 & 21236 & 30015 & 49688 \\
\hline $\begin{array}{c}\text { Republic of } \\
\text { Tatarstan }\end{array}$ & 6278 & 5376 & 12855 & 22279 & 31530 & 56981 \\
\hline $\begin{array}{c}\text { Penzenskaya } \\
\text { oblast }\end{array}$ & 6057 & 977 & 13171 & 22606 & 30986 & 47462 \\
\hline $\begin{array}{l}\text { Republic of } \\
\text { Udmurtia }\end{array}$ & 6375 & 5328 & 15386 & 25770 & 35815 & 56120 \\
\hline
\end{tabular}

Regions of the Volga Federal District can be characterized by the high differentiation of living standards. The achieved level of inequality prevents households to move to the middle and upper classes. One possible way out is gradual raise of the minimum wage, making it equal to the amount of subsistence minimum and exceeding it at a level where individual could satisfy all his needs. Another solution is connected with the targeted social policy, which gives social protection to the 
vulnerable group of households, implements adequate social guarantees, pensions and worthy medical insurance.

\section{CONCLUSION}

Based on the research, the following conclusions are made:

1. The majority of households in almost all regions belong to the lower-middle class (second group), but not to the middle class (third group). Percentage is different for these regions, but on average, it is $38.9 \%$. Only two regions: the Republic of Mordovia and the Republic of Udmurtia, have more households in the third group which refers to the middle class. The first hypothesis is refuted.

2. In almost all regions of the Volga Federal District, the percentage of households below the relative poverty line is less than $10 \%$. The second hypothesis is confirmed.

3. In all regions, the proportion of households in the upper-middle and upper class together does not exceed $30 \%$ of the whole sample. The third hypothesis is confirmed.

\section{Acknowledgment}

This work was supported by the research grant of Kazan Federal University.

\section{References}

[1] Y. Chung, J. Isaacs and T. Smeeding, "Advancing Poverty Measurement and Policy: Evidence from Wisconsin during the Great Recession", Social Service Review, vol. 87, no. 3, pp. 525-555, 2013.

[2] P. Annoni, R. Bruggemann and L. Carlsen, "A multidimensional view on poverty in the European Union by partial order theory", Journal of Applied Statistics, vol. 42, no. 3, pp. 535-554, 2014.

[3] N. Longford, M. Pittau, R. Zelli and R. Massari, "Poverty and inequality in European regions", Journal of Applied Statistics, vol. 39, no. 7, pp. $1557-1576,2012$.
[4] J. Han, R. Liu and J. Zhang, "Globalization and wage inequality: Evidence from urban China", Journal of International Economics, vol. 87, no. 2, pp. 288-297, 2012.

[5] L. Zanin, "On Italian Households' Economic Inadequacy Using QualiQuantitative Measures", Social Indicators Research, vol. 128, no. 1, pp. 59-88, 2015.

[6] R. Cerqueti and M. Ausloos, "Statistical assessment of regional wealth inequalities: the Italian case", Quality \& Quantity, vol. 49, no. 6, pp. 2307-2323, 2014

[7] P. Annoni and D. Weziak-Bialowolska, "A Measure to Target Antipoverty Policies in the European Union Regions", Applied Research in Quality of Life, vol. 11, no. 1, pp. 181-207, 2014.

[8] E. Skoufias and R. Katayama, "Sources of welfare disparities between and within regions of Brazil: evidence from the 2002-2003 household budget survey (POF)", Journal of Economic Geography, vol. 11, no. 5, pp. 897-918, 2010.

[9] I. Ali, A. Barrientos, A. Saboor, A. Khan and J. Nelson, "A Decade of Sub-national Pro-poor Growth in Pakistan", Social Indicators Research, vol. 133 , no. 1, pp. 47-65, 2016.

[10] J. Varlamova and N. Larionova, "Macroeconomic and Demographic Determinants of Household Expenditures in OECD Countries", Procedia Economics and Finance, vol. 24, pp. 727-733, 2015.

[11] J. Klugman, "Poverty in Russia: An assessment", World Bank Report, No. 14110-RU, 1998

[12] B. Milanovic, Income, inequality and poverty during the transition from planned to market economy. Washington, D.C.: The World Bank, 1998.

[13] B. Bradbury, S. Jenkins and J. Micklewright, Child poverty dynamics in seven nations. Florence: Unicef, United nations children's fund, Innocenti resarch centre, 2000.

[14] I. Korchagina and L. Ovcharova, Indicators of poverty in transitional Russia. Moscow: Economic Education and Research Consortium, 1998.

[15] J. Braithwaite and A. Ivanova "Economies of Scale \& Poverty Lines: Russia 1994-1996", Moscow: The World Bank, 1998.

[16] R. Sadyrtdinov and E. Beglova, "Equivalence Scale Estimation for Regions of the Russian Federation". In Kliestik T, editor, Globalization and its Socio-economic Consequences, 16th International Scientific Conference Proceedings, PTS I-V. University Zilina, Faculty Operation \& Economics Transport \& Communication. 2016. p. 734-740.

[17] Budget Survey of Households in Russian Federation 2012. Retrieved from: http://obdx.gks.ru/ 